\title{
Determination of pre-service science teachers' attitudes towards reading science texts
}

\author{
Şendil Can, Gülperi Öztürk
}

Education Faculty, Muğla Sttkı Koçman University, Turkey

\begin{tabular}{l}
\hline Article Info \\
\hline Article history: \\
Received Dec 7, 2018 \\
Revised Jan 25, 2019 \\
Accepted Feb 8, 2019 \\
\hline
\end{tabular}

Keywords:

Attitude

Determinant factors

Pre-service science teachers

Science texts

\begin{abstract}
The purpose of the current study is to determine the effects of the variables such as gender, grade level, grade point average and book reading frequency on pre-service science teachers' attitudes towards science texts. The sampling of the current study is comprised of 103 pre-service science teachers enrolled at the Education Faculty of Muğla Sitk1 Koçman University in the spring term of 2017-2018 academic year. In the current study, in order to determine the pre-service teachers' attitudes towards reading science texts, "The Scale of Attitudes towards Reading Science Texts" was used. The effects of gender and grade level on the pre-service science teachers' attitudes towards reading science texts were analyzed with independent samples t-test and the effects of academic achievement and book reading frequency were analyzed with one-way variance analysis (ANOVA). As a result of the study, it was concluded that the gender and grade level variables have significant effects on the pre-service teachers' attitudes towards reading science texts in the sub-dimensions of making use of science texts when possible, denial and contribution of reading science texts to learning and skills and that the general grade point average and book reading frequency have significant effects on the pre-service teachers' attitudes towards reading science texts in the sub-dimension of making use of science texts when possible.
\end{abstract}

Copyright $($ C) 2019 Institute of Advanced Engineering and Science. All rights reserved.

\section{Corresponding Author:}

Şendil Can,

Education Faculty,

Muğla Sitkı Koçman University.

Kötekli Mahallesi, 48000 Menteşe/Muğla, Turkey

Email: csendil@mu.edu.tr

\section{INTRODUCTION}

The ability to read and write in science education is an effective and important prerequisite for educating science literate individuals. Today, students are provided with different ways to understand science. One of them is science texts that can be used with both primary, high school and university students. Science texts can play an important role for students to gain the reading habit and to love science. Thus, they are widely used in the learning process. Students' interests in and attitudes towards science are increased by using the science texts and thus permanent and meaningful learning is ensured.

Reading is one of the most important ways to keep the current information constantly updated and to improve it [1]. Reading is a process covering both dynamic and static texts and involving the efforts a reader to make sense of a text [2]. Moreover, reading is understanding a known written text with emotions and thoughts expressed in it rather than voiced or voiceless expression of its writing characters [1]. Meaning is a tool emerging in the process of reading [3]. However, reading comprehension does not mean only making sense of the words in the text and finding their meanings in the dictionary. Comprehension refers to correct understanding of the text by the reader [1]. Good readers have been found to know which strategies to use 
while reading a text whereas poor readers experience problems in understanding a text and they are not good at finding solutions to these problems [4].

Students are required to understand what they have read in order to be academically successful in different courses they take throughout their education life. Therefore, if students have problems understanding what they read, they may face serious problems in the education process [5].

Students' inability to use scientific language is due to their lack of reading and writing skills. This accordingly decreases achievement in science courses. In this regard, reading of science texts will enable students to have information about themselves and to contribute to the development of their monitoring and personal skills and to be successful in science [6]. In the content of the texts used in science education, the attention problem between the text superstructure and the grip is considered to be an important problem [7]. Reading the competences of science-based knowledge in the field, being aware of the competence knowledge, is also an indicator of successful problem-solving [8].

Effective science text reading involves not only the quest and analysis of information obtained from many different materials and multimedia (schemes, animations, videos and mathematical symbols) but also involves determining the objective of reading, using reading strategies and the ways of reaching comprehension [9]. Thus it can be argued that enhancing the efficiency of science texts in science teaching will make important contributions to improving students' reading habits.

Science texts are informative texts. Being informative texts, science texts enable readers of science texts to improve their knowledge and to develop their research-inquiry and discussion skills. Moreover, they should reflect events and phenomena from the real world. Clear and comprehensible science texts make it easier for readers to understand.

Science texts have concrete contents consisted of scientific information. Reading of scientific texts does not only involve the translation of printed symbols; it also requires interactions with the prior knowledge of the reader and improves reading comprehension skill in science texts [2]. Transfer of scientific knowledge occurs through the reading of science texts. Science texts utilized for the purpose of learning also encompasses strategies such as gaining information about the subject, elaboration of subjects about which little is known, construction of new information on the basis of prior knowledge [10].

The phenomenon acquired as a result of learning, affecting individuals' behaviors and leading to being biased in decision making is called the attitude. Moreover, the attitude is people' response given to a certain object and including some bias in it [11].

"The attitudes towards science in general, a specific science topic or activity, scientific research approaches, people working in the field of science, reading books on science topics, technological applications based on the products and findings of science and the relations of science with the society in particular are called science teaching-related attitudes." [7], [12].

As attitudes affect behaviors, they are important. Attitude is effective in coping with emotions that arise at the time of learning and directing human behavior. Seen from this perspective, science education should be aimed at improving students' knowledge, interests, abilities and attitudes [13].

In their study, Bektaş Esen and Yiğit [6] examined the students' reading and writing strategies used in science and technology courses, and examined whether these strategies vary significantly depending on gender, academic achievement and class level variables. The study was conducted with the participation of elementary school $5^{\text {th }}, 6^{\text {th }}, 7^{\text {th }}$ and $8^{\text {th }}$ grade students attending elementary schools in the city of Giresun. It was found that the students used the strategies of self-questioning, visualizing what they have read in their minds, underlining important places and organizing their writing than other strategies in order to be more successful in reading. It was concluded that they might have used some strategies less as they viewed writing as requiring great amount of effort and time and they might have been better at some strategies as they thought that they helped them to create effective links with the text.

Nigro and Trivelato [7] aimed to evaluate the knowledge and attitudes related to the reading from different science disciplines. The study was conducted on randomly selected 220 students aged at 14-15. It was concluded that the females have higher scores than the males and the students having read the science texts have higher scores than the students having read the textbook. The attitude towards the text to be read was found to be an important factor in explaining the behaviors of the children having read the popular scientific text. In addition to this, the tests administered revealed that the good readers from among the children having read the popular scientific text were found to have got lower scores than their counterparts having read the textbook.

İşeri [14] conducted a study to investigate elementary school students' reading attitudes in terms of some variables by using the "The Reading Attitude Scale for the Elementary Education Second Level Students" developed by Özbay and Uyar (2009). The study group was comprised of $5086^{\text {th }}, 7^{\text {th }}$ and $8^{\text {th }}$

Int. J. Eval. \& Res. Educ. Vol. 8, No. 1, March 2019: 181 - 188 
graders attending elementary schools located in the city of Niğde. The study employed the survey model. The findings related to the sub-problems were analyzed with independent sample $t$ test and one way ANOVA. As a result of the study, it was concluded that the elementary school second level students have positive reading attitudes. It was also found that the elementary school second level students' reading attitude mean scores vary significantly depending on the gender, the school attended and the grade level.

In their study, Ateş and Başaran [15] aimed to determine elementary school fifth grade students' attitudes towards reading and the extent to which these attitudes are affected from some variables. The universe of the study is comprised of fifth grade students attending the elementary schools in the districts of the Sorgun and Saraykent provinces in the city of Yozgat and in the Çankaya district of the city of Ankara. From among the students making up the universe, 601 students were reached for the current study. In the current study employing the field study method the data were collected through a questionnaire developed by the researcher. As a result of the study, it was found that majority of the students have positive attitudes towards reading.

Sallabaş [16] conducted a study to determine whether there is a relationship between the eighth grade students' reading comprehension skills and their developing positive attitudes towards reading. Two informative and two narrative texts with 143 multiple-choice questions were given to the eighth grade students. These questions were used to determine the extent to which the students understand the texts. Moreover, 20-item "The Scale of Attitude towards Reading" developed by the researcher was used to collect data. The collected data were analyzed by using the suitable analyses in SPSS-11.5 program package. T-test was used to determine the relationship between two variables. In order to determine the correlation between the scales, correlation analysis was used. According to the results of the study, there is a weak correlation between the students' attitudes towards reading and reading comprehension skills. Moreover, a medium level correlation was found between the students' reading comprehension skills and academic achievement

Akgün, Aydın and Öner Sünkür [13] aimed to investigate the attitudes of the students from the elementary education department on the basis of gender, branch, achievement, father and mother's education level and family income towards science courses. The study was conducted with the participation of 341 students attending the science, math and classroom teaching programs of the elementary education department of Ziya Gökalp Education Faculty in Dicle University in 2006-2007 academic year. It was found that the pre-service science, math and classroom teachers' attitudes towards science courses depending on gender, branch, achievement, father's education level and family income varied significantly.

Ünal [17] investigated the relationship between the critical reading skills, reading attitudes and reading comprehension levels of the $5^{\text {th }}$ grade students attending elementary schools located in the city of Eskişehir. The data of the study were collected from 1012 students enrolled at 14 different elementary schools and for the collection of the data, the critical reading scale, the scale of attitudes towards reading and the reading comprehension test were used. In the analysis of the collected data, arithmetic means, standard deviations and correlation analysis methods were used. As a result of the study, it was found that there is a significant and high correlation between the students' attitudes towards reading and critical thinking skill. Moreover, a significant and medium correlation was found between the students' reading comprehension level and critical thinking skill level.

U. Serin, O. Serin and Kesercioğlu [12] attempted to determine pre-service teachers' attitudes towards science. The sampling of the study is comprised of a total of 409 students attending the departments of science teaching of Buca Education Faculty in Dokuz Eylül University and of Demirci Education Faculty in Celal Bayar University. As a result, the participating pre-service teachers' attitudes towards science were found to be at the medium level. The pre-service teachers' attitudes towards science were found to be varying significantly depending on their state of satisfaction with the department attended and instruction given there. Moreover, the pre-service teachers' attitudes towards science were found to be varying significantly depending on the university attended, gender, type of the high school graduated, high school grad point average, mother and father's education level but not varying significantly depending on the other demographic features.

For both pre-service science teachers and all students, reading scientific information is important in their educational and professional lives and reading and comprehending science texts is of vital importance in the field of science. This naturally increases the importance of positive attitudes towards science texts. In the literature, it is seen that the amount of research on science texts is inadequate. Thus, it is believed that investigation of the attitudes towards science texts on the basis of different variables will make contributions to the literature. In this connection, the purpose of the current study is to determine the effects of the variables such as gender, grade level, grade point average and book reading frequency on pre-service science teachers' attitudes towards science texts. 


\section{RESEARCH METHOD}

The current study is a quantitative study employing the survey model used to collect data to determine the some specific features of a group [18]. The sampling of the study is comprised of a total of 103 (42 are first-year students and 61 are fourth-year students) pre-service science teachers attending the Education Faculty in Muğla Sitkı Koçman University in the spring term of 2017-2018 academic year. In the current study, "The Scale of Attitudes towards Science Texts" developed by Yürük, Gülfem Kumlu and Gökhan Kumlu [19] was used to determine the attitudes of the pre-service teachers towards reading science texts. This scale is a five-point Likert scale, which consists of 30 items and three sub-dimensions, which are "Making use of science texts when possible", "Denial" and "Contribution of science texts to learning and skills. Of the 30 items in the scale, 18 are positive and 12 are negative. The Cronbach Alpha internal consistency coefficient of the original scale was found to be 0.94 for the whole scale and $0.92,0.92$ and 0.86 for the sub-scales, respectively. The internal consistency coefficients calculated on the data collected in the current study were found to be $0.94,0.89,0.90$ and 0.85 , respectively.

\section{RESULTS AND DISCUSSION}

For the positive items in the scale, the scoring is performed as: "Strongly agree" (5), "Agree" (4), "Undecided" (3), "Disagree" (2) and "Strongly disagree" (1) while for the negative items, the scoring is reversed. The effects of gender and grade level on the pre-service teachers' attitudes towards reading science texts were analyzed with independent-samples t-test and the effects of academic achievement and book reading frequency were analyzed with one-way variance analysis (ANOVA).

In this section, the collected data are analyzed by using the suitable statistical methods and then presented in tables and interpreted.

\subsection{Findings related to the sub-question "Do the pre-service science teachers' attitudes towards reading science texts vary significantly by gender?"}

In order to find an answer to this sub-problem, independent samples t-test was run to determine whether the scores taken from the sub-dimensions of "The Scale of Attitudes towards Science Texts" vary significantly depending on the gender variable. The results are presented in Table 1.

Table 1. Results of the T-test conducted to determine whether the pre-service science teachers' scores taken from the sub-dimensions of the scale vary significantly depending on gender

\begin{tabular}{cccccccc}
\hline Sub-dimensions & Gender & $\mathrm{N}$ & $\bar{X}$ & $\mathrm{~S}$ & $\mathrm{Sd}$ & $\mathrm{t}$ & $\mathrm{P}$ \\
\hline Making Use of Science Texts When & Female & 87 & 41.60 & 6.82 & 101 & 2.03 & .04 \\
Possible & Male & 16 & 37.79 & 8.37 & & & \\
Denial & Female & 87 & 47.49 & 8.03 & 101 & 3.13 & .00 \\
& Male & 16 & 40.19 & 11.17 & & & \\
Contribution of Reading Science & Female & 87 & 28.57 & 4.51 & 101 & 2.39 & .01 \\
Texts to Learning and Skills & Male & 16 & 25.50 & 5.79 & & & \\
\hline
\end{tabular}

As can be seen in Table 1, 87 of the participating pre-service teachers are females and 16 are males. The pre-service science teachers' attitudes towards reading science texts were found to be varying significantly by gender in the sub-dimensions of "making use of science texts when possible", "denial" and "contribution of reading science texts to learning and skills" $\left[\mathrm{t}_{(101)}=2.03 ; \mathrm{p}<.05\right],\left[\mathrm{t}_{(101)}=3.13 ; \mathrm{p}<.05\right],\left[\mathrm{t}_{(101)}\right.$ $=2.39 ; \mathrm{p}<.05]$. This difference was found to be in favor of the female pre-service teachers in all the subdimensions ( $\bar{X}=41.60,47.49$ and 28.57). Thus, it was concluded that gender created a significant difference in their attitudes towards reading science texts. In their study aiming to evaluate the knowledge and attitudes related to reading from different science disciplines, Nigro ve Trivelato [7] found that the females got higher scores than the males and the readers of the popular scientific texts got higher scores than their counterparts having read the textbook. This finding concurs with the finding of the current study. There are also some other studies reaching different conclusions in the literature. Akgün, Aydın and Öner Sünkür [13] found that the students' attitudes towards science courses vary significantly depending on gender; yet, this difference is in favor of the male students. U. Serin, O. Serin and Kesercioğlu [12] concluded that the students' science attitude scores do not vary significantly depending on gender and that the attitudes of female and male students towards science are similar.

Int. J. Eval. \& Res. Educ. Vol. 8, No. 1, March 2019: 181 - 188 
3.2. Findings related to the sub-question "Do the pre-service science teachers' attitudes towards reading science texts vary significantly depending on grade level?"

In order to find an answer to this sub-problem, independent samples t-test was run to determine whether the scores taken from the sub-dimensions of "The Scale of Attitudes towards Science Texts" vary significantly depending on the grade level variable. The results are presented in Table 2.

Table 2. Results of the T-test conducted to determine whether the pre-service science teachers' scores taken from the sub-dimensions of the scale vary significantly depending on grade level

\begin{tabular}{|c|c|c|c|c|c|c|c|}
\hline Sub-dimensions & Grade Level & $\mathrm{N}$ & $\bar{X}$ & $\mathrm{~S}$ & $\mathrm{Sd}$ & $\mathrm{t}$ & $\mathrm{P}$ \\
\hline Making Use of Science Texts When & $1^{\text {st }}$ year & 42 & 38.26 & 6.32 & 101 & -3.36 & .00 \\
\hline Possible & $4^{\text {th }}$ year & 61 & 42.87 & 7.18 & & & \\
\hline \multirow[t]{2}{*}{ Denial } & $1^{\text {st }}$ year & 42 & 44.23 & 8.01 & 101 & -2.03 & .04 \\
\hline & $4^{\text {th }}$ year & 61 & 47.82 & 9.30 & & & \\
\hline Contribution of Reading Science Texts & $1^{\text {st }}$ year & 42 & 26.55 & 4.71 & 101 & -2.79 & .01 \\
\hline to Learning and Skills & $4^{\text {th }}$ year & 61 & 29.16 & 4.66 & & & \\
\hline
\end{tabular}

As can be seen in Table 2, of the participating pre-service teachers, 42 are first-year students and 61 are fourth-year students. The pre-service science teachers' attitudes towards reading science texts were found to be varying significantly by grade level in the sub-dimensions of "making use of science texts when possible", "denial" and "contribution of reading science texts to learning and skills" $\left[\mathrm{t}_{(101)}=-3.36 ; \mathrm{p}<.05\right]$, $\left[\mathrm{t}_{(101)}=-2.03 ; \mathrm{p}<.05\right],\left[\mathrm{t}_{(101)}=-2.79 ; \mathrm{p}<.05\right]$. This might be interpreted as the grade level variable significantly affects the pre-service teachers' attitudes towards reading science texts. The fourth-year preservice science teachers' attitudes towards reading science texts were found to be more positive in all the sub-dimensions ( $\bar{X}=42.87,47.82$ and 29.16) than those of the first-year pre-service science teachers $(\bar{X}=$ $38.26,44.23$ and 26.55). There are some studies finding different results in the literature. Bektaş Esen and Yiğit [6] found a significant difference in terms of the use of reading and writing strategies depending on grade level. This difference is in favor of the fifth grade students.

3.3. Findings related to the sub-question "Do the pre-service science teachers' attitudes towards reading science texts vary significantly depending on grade point average?"

In order to find an answer to this sub-problem, ANOVA was run to determine whether the scores taken from the sub-dimensions of "The Scale of Attitudes towards Science Texts" vary significantly depending on the grade point average variable. The results are presented in Table 3 and Table 4.

Table 3. Arithmetic means and standard deviations for the pre-service science teachers' scores taken from the sub-dimensions of the attitude scale depending on grade point average

\begin{tabular}{|c|c|c|c|c|}
\hline Sub-dimensions & \multirow{2}{*}{$\begin{array}{l}\text { General Point Average } \\
1.00-1.99\end{array}$} & \multirow{2}{*}{$\begin{array}{l}\mathrm{N} \\
13\end{array}$} & \multirow{2}{*}{$\frac{\overline{\mathrm{X}}}{36.38}$} & \multirow{2}{*}{$\begin{array}{c}\mathrm{S} \\
9.22\end{array}$} \\
\hline Making Use of Science Texts When & & & & \\
\hline Possible & $2.00-2.99$ & 66 & 40.94 & 6.84 \\
\hline & $3.00-4.00$ & 24 & 43.63 & 5.75 \\
\hline & Total & 103 & 40.99 & 7.18 \\
\hline \multirow[t]{4}{*}{ Denial } & $1.00-1.99$ & 13 & 3.65 & .68 \\
\hline & $2.00-2.99$ & 66 & 3.88 & .78 \\
\hline & $3.00-4.00$ & 24 & 3.93 & 69 \\
\hline & Total & 103 & 3.86 & .74 \\
\hline Contribution of Reading Science Texts to & $1.00-1.99$ & 13 & 3.69 & 87 \\
\hline \multirow[t]{3}{*}{ Learning and Skills } & $2.00-2.99$ & 66 & 4.00 & .65 \\
\hline & $3.00-4.00$ & 24 & 4.20 & .66 \\
\hline & Total & 103 & 4.01 & .69 \\
\hline
\end{tabular}

As can be seen in Table 3, 13 of the pre-service teachers have a grade point average in the range $1.00-1.99,66$ in the range 2.00-2.99 and 24 in the range 3.00-4.00. The results of ANOVA conducted to determine whether the students' attitudes towards the sub-dimensions of the attitude scale vary significantly depending on grade point average are given in Table 4. 
Table 4. The results of ANOVA conducted to determine whether the pre-service teachers' mean scores taken from the sub-dimensions vary significantly depending on grade point average

\begin{tabular}{|c|c|c|c|c|c|c|c|}
\hline Sub-dimensions & $\begin{array}{c}\text { Source of the } \\
\text { variance }\end{array}$ & $\begin{array}{l}\text { Sum of } \\
\text { Squares }\end{array}$ & $\mathrm{sd}$ & $\begin{array}{l}\text { Mean of } \\
\text { Squares }\end{array}$ & $\mathrm{F}$ & $\mathrm{p}$ & $\begin{array}{l}\text { Significant } \\
\text { Difference }\end{array}$ \\
\hline Making Use of Science & Between-groups & 442.53 & 2 & 221.27 & 4.59 & .01 & $3.00-4.00>1.00-1.99$ \\
\hline \multirow[t]{3}{*}{ Texts When Possible } & Within-groups Total & 4818.46 & 100 & 48.19 & & & \\
\hline & & 5260.99 & 102 & & & & \\
\hline & Between-groups & .74 & 2 & .37 & .68 & .52 & \\
\hline \multirow[t]{2}{*}{ Denial } & Within-groups & 55.81 & 100 & .56 & & & - \\
\hline & Total & 56.55 & 102 & & & & \\
\hline Contribution of Reading & Between-groups & 2.19 & 2 & 1.09 & 2.37 & .09 & - \\
\hline Science Texts to & Within-groups Total & 46.43 & 100 & .46 & & & \\
\hline Learning and Skills & & 48.63 & 102 & & & & \\
\hline
\end{tabular}

As can be seen in Table 4, while the pre-service science teachers' attitudes towards reading science texts vary significantly depending on grade point average in the sub-dimension of "making use of science texts when possible" $\left[\mathrm{F}_{(2-100)}=4.59, \mathrm{p}<.05\right]$, they do not vary significantly in the sub-dimensions of "denial" and "contribution of reading science texts to learning and skills" $\left[\mathrm{F}_{(2-100)}=.68, \mathrm{p}>.05\right],\left[\mathrm{F}_{(2-100)}=2.37, \mathrm{p}>\right.$ $.05]$. The pre-service teachers with a grade point average in the range 3.00-4.00 were found to have more positive attitudes towards the sub-dimension of "making use of science texts when possible" than the preservice teachers with a grade point average in the range 1.00-1.99. Akgün, Aydın and Öner Sünkür [13] found that there is a significant correlation between the students' science achievement and their attitude scores and concluded that the attitudes of the students with science achievement classified as "very good", "good" and "medium" are more positive than the students with science achievement classified as "low". This supports the finding of the current study.

3.4. Findings related to the sub-question "Do the pre-service science teachers' attitudes towards reading science texts vary significantly depending on book reading frequency?"

In order to find an answer to this sub-problem, ANOVA was run to determine whether the scores taken from the sub-dimensions of "The Scale of Attitudes towards Science Texts" vary significantly depending on book reading frequency. The results are presented in Table 5 and Table 6.

Table 5. Arithmetic means and standard deviations for the pre-service science teachers' scores taken from the sub-dimensions of the attitude scale depending on book reading frequency

\begin{tabular}{llccc}
\hline \multicolumn{1}{c}{ Sub-dimensions } & Book Reading Frequency & $\mathrm{N}$ & $\overline{\mathrm{X}}$ & $\mathrm{S}$ \\
\hline & Every day & 10 & 3.95 & .72 \\
& Once every other day & 10 & 3.71 & .81 \\
Making Use of Science Texts When & Once a week & 20 & 3.79 & .54 \\
Possible & Once a month & 39 & 3.93 & .53 \\
& Once a year & 18 & 3.34 & .56 \\
& Never & 6 & 3.03 & .86 \\
& Total & 103 & 3.73 & .65 \\
& & & & \\
& Every day & 10 & 3.87 & .94 \\
& Once every other day & 10 & 4.20 & .67 \\
Denial & Once a week & 20 & 3.99 & .55 \\
& Once a month & 39 & 3.93 & .78 \\
& Once a year & 18 & 3.59 & .68 \\
& Never & 6 & 3.22 & .62 \\
& Total & 103 & 3.86 & .74 \\
& & & & \\
Learning and Skills & Every day & 10 & 4.15 & .74 \\
& Once every other day & 10 & 4.04 & .82 \\
& Once a week & 20 & 4.02 & .63 \\
& Once a month & 39 & 4.19 & .55 \\
& Once a year & 18 & 3.68 & .64 \\
& Never & 6 & 3.52 & 1.15 \\
& Total & 103 & 4.01 & .69 \\
\hline
\end{tabular}

As can be seen in Table 5, the highest number of students are in the frequency group "once a month" $(\mathrm{N}=39)$ in all the sub-dimensions and the smallest number of students are in the frequency group "never" $(\mathrm{N}=6)$. In order to determine whether the difference between the arithmetic means is statistically significant, variance analysis was conducted. The findings are presented in Table 6.

Int. J. Eval. \& Res. Educ. Vol. 8, No. 1, March 2019: 181 - 188 
Table 6. The results of ANOVA conducted to determine whether the pre-service teachers' mean scores taken from the sub-dimensions vary significantly depending on book reading frequency

\begin{tabular}{|c|c|c|c|c|c|c|c|}
\hline Sub-dimensions & $\begin{array}{l}\text { Source of the } \\
\text { variance }\end{array}$ & Sum of Squares & sd & $\begin{array}{l}\text { Mean of } \\
\text { Squares }\end{array}$ & $\mathrm{F}$ & $\mathrm{p}$ & Significant Difference \\
\hline Making Use of & Between-groups & 7.85 & 5 & 1.55 & 4.22 & .00 & Every day $>$ Once a year \\
\hline Science Texts & Within-groups Total & 35.71 & 97 & .37 & & & \\
\hline \multirow[t]{2}{*}{ When Possible } & & 43.48 & 102 & & & & \\
\hline & Between-groups & 5.44 & 5 & 1.08 & 2.06 & .08 & \\
\hline \multirow[t]{2}{*}{ Denial } & Within-groups Total & 51.11 & 97 & .53 & & & - \\
\hline & & 56.55 & 102 & & & & \\
\hline Contribution of & Between-groups & 4.85 & 5 & .97 & 2.15 & .06 & \\
\hline Reading Science & Within-groups Total & 43.78 & 97 & .45 & & & - \\
\hline $\begin{array}{l}\text { Texts to Learning } \\
\text { and Skills }\end{array}$ & & 48.63 & 102 & & & & \\
\hline
\end{tabular}

As can be seen in Table 6, the pre-service science teachers' attitudes towards reading science texts vary significantly depending on book reading frequency in the sub-dimension of "making use of science texts when possible" $\left[\mathrm{F}_{(5-97)}=4.22, \mathrm{p}<.05\right]$. This is because the attitudes of the pre-service teachers reading book every day towards reading science texts $(\bar{X}=3.95)$ are more positive than the pre-service teachers reading once a year $(\bar{X}=3.34)$. Yet, the pre-service science teachers' attitudes towards reading science texts do not vary significantly depending on book reading frequency in the sub-dimensions of "denial" and "contribution of reading science texts to learning and skills" $\left[\mathrm{F}_{(5-97)}=2.06, \mathrm{p}>.05\right],\left[\mathrm{F}_{(5-97)}=2.15, \mathrm{p}>.05\right]$. This can be interpreted as the pre-service teachers' book reading frequency significantly affects their attitudes in the subdimension of "making use of science texts when possible"; yet, it does not significantly affect their attitudes in the sub-dimensions of "denial" and "contribution of reading science texts to learning and skills". The courses taken during their four-year undergraduate education about science instruction may have positively affected their attitudes towards reading science texts. Güneyli [20] conducted a study on 160 pre-service teachers found that the students were better at comprehending informative texts when compared to literary texts. This finding can be argued to be parallel to the finding of the current study related to the sub-dimension of "making use of science texts when possible". On the other hand, in a study by Balc1 [3], no significant difference was found between the reading comprehension scores of the $8^{\text {th }}$ grade students taken from different text genres. This finding concurs with the finding of the current study related to the sub-dimensions of "denial" and "contribution of reading science texts to learning and skills"

\section{CONCLUSION}

The current study was conducted to determine the effects of variables such as gender, grade level, academic achievement and book reading frequency on the pre-service science teachers' attitudes towards reading science texts. The results obtained to this end are presented below. The pre-service science teachers' attitudes towards reading science texts vary significantly by gender in the sub-dimensions of "making use of science texts when possible", "denial" and "contribution of reading science texts to learning and skills" and the attitudes of the female pre-service teachers are more positive than those of the male pre-service teachers. It was also found that the pre-service science teachers' attitudes towards reading science texts vary significantly depending on grade level in the sub-dimensions of "making use of science texts when possible", "denial" and "contribution of reading science texts to learning and skills and the attitudes of the fourth-year students are more positive than those of the first-year students. The pre-service teachers' attitudes towards reading science texts were found to be varying significantly depending on grade point average in the subdimension of "making use of science texts when possible" and the pre-service teachers with a grade point average in the range 3.00-4.00 have more positive attitudes; yet, their attitudes were found to be not varying significantly depending on grade point average in the sub-dimensions of "denial" and "contribution of reading science texts to learning and skills". The pre-service science teachers' attitudes were found to be varying significantly depending on book reading frequency in the sub-dimension of "making use of science texts when possible" and the attitudes of the pre-service teachers reading every day towards reading science texts were found to be more positive than those of the students reading once a year. Book reading frequency was not found to be influential on the attitudes towards the sub-dimensions of "denial" and "contribution of reading science texts to learning and skills."

The attitudes of male students towards reading science texts can be improved by making them more active through the activities to be developed to this end. From their first year onwards, pre-service science teachers should be introduced to activities to encourage them to read science texts and they should be assigned with projects that will contribute to the development of their attitudes and their learning and skills. 


\section{REFERENCES}

[1] Karatay, H., "İlköğretim türkçe öğretmeni adaylarının okuduğunu anlama becerileri üzerine alan araştırması," Yayınlanmış Doktora Tezi. Ankara: Gazi Üniversitesi Eğitim Bilimleri Enstitüsü, 2007.

[2] Michalsky, T., "Integrating skills and wills instruction in self-regulated science text reading for secondary students," International Journal of Science Education, vol. 35(11), pp. 1846-1873, 2013.

[3] Balc1, A., "İlköğretim 8. sınıf öğrencilerinin okumaya yönelik tutumları ve okuduğunu anlama düzeyleri,"Education Sciences, vol. 4(4), pp. 1308-1330, 2009.

[4] Başöncül, N. ve Oluk, S., "İlköğretim 8. Sınıf öğrencilerin üstbiliş̧ okuma stratejilerini kullanma düzeyleri ile fenteknoloji ve türkçe ders başarıları üzerine etkisi," Kastamonu Ĕgitim Dergisi, vol. 17(1), pp. 183-194, 2009.

[5] Güngör, A., "Altınc1, yedinci ve sekizinci sınıf öğrencilerinin okuduğunu anlama stratejilerini kullanma düzeyleri," Hacettepe Üniversitesi Eğitim Fakültesi Dergisi, vol. 28, pp. 101-108, 2005.

[6] Bektaş Esen, E. ve Yiğit, N., "Öğrencilerin fen ve teknoloji dersinde kullandıkları okuma ve yazma stratejileri," Fen Bilimleri Öğretimi Dergisi, vol. 1(1), pp. 23-42, 2013.

[7] Nigro, R. G. \& Trivelato, S. F., "Knowledge, its application, and attitudes associated with the reading of diverse genres of science texts,"International Journal of Science Education, vol. 34(16), pp. 2529-2564, 2012.

[8] Yang, F. Y., Chang, C. C., Chen, L. L. \& Chen, Y. C., "Exploring learners' beliefs about science reading and scientific epistemic beliefs, and their relations with science text understanding," International Journal of Sclence Education, vol. 38(10), pp. 1591-1606, 2016.

[9] Yen, M. H., Wang, C. Y., Chang, W. H., Chen, S., Hsu, Y. S. \& Liu, T. C., "Assessing metacognitive components in self-regulated reading of science texts in e-based environments," International Journal of Science and Mathematics Education, vol. 16(5), pp. 797-816, 2018.

[10] Bayat, N. ve Yüce, S., "Metaforik açımlamanın fen metinlerini anlamaya etkisi," Journal of Language Education and Research, vol. 1(3), pp. 1-14, 2015.

[11] Usta, A.,"İlköğretim fen bilgisi derslerinde öğrenme stillerine dayalı öğretim etkinliklerinin öğrenci erişi ve tutumlara etkisi," Yayınlanmış Yüksek Lisans Tezi. Konya: Selçuk Üniversitesi Sosyal Bilimler Enstitüsü, 2006.

[12] Serin, U., Serin, O. ve Kesercioğlu, T., "Eğitim fakülteleri ilköğretim bölümü öğrencilerinin fen bilimlerine yönelik tutumlarının bazı değiş̧kenler açısından karşılaştırılması," Eğitim ve Bilim, vol. 30(138), pp. 38-44, 2005.

[13] Akgün, A., Aydın, M. ve Sünkür, M.Ö., "İlköğretim bölümü öğrencilerinin fen derslerine yönelik tutumlarının çeşitli değişkenlere göre incelenmesi," A.Ü. Bayburt Ĕ̆itim Fakültesi Dergisi, vol. 2(2), pp. 1-14, 2007.

[14] İşeri, K., "İlköğretim ikinci kademe öğrencilerinin okuma tutumlarının incelenmesi," Uluslararası İnsan Bilimleri Dergisi, vol. 7(2), pp. 468-487, 2010.

[15] Ateş, S. ve Başaran, M. "İlköğretim beşinci sınıf öğrencilerinin okumaya ilişkin tutumlarının incelenmesi," Gazi Ĕ̈itim Fakültesi Dergisi, vol. 29(1), pp. 73-92, 2009.

[16] Sallabaş, M. E., "zRelationship between 8th grade secondary school students' reading attitudes and reading comprehension skills," Inönü University Journal of the Faculty of Education, vol. 9(16), pp. 141-155, 2008.

[17] Ünal, E. "İlköğretim öğrencilerinin eleştirel okuma becerileri ile okuduğunu anlama ve okumaya ilişkin tutumları arasındaki ilişki," Yayınlanmış Yüksek Lisans Tezi. Eskişehir: Eskişehir Osmangazi Üniversitesi Sosyal Bilimler Enstitüsü, 2006.

[18] Akgün, Ö. E., Büyüköztürk, Ş., Demirel, F., Karadeniz Ş. ve Kılıç Çakmak, E., "Bilimsel araştırma yöntemleri (21. Baskı)," Pegem Yayınları, Ankara 2016.

[19] Kumlu, G. D., Kumlu, G. ve Yürük, N. "Üniversite öğrencileri için fen metinlerini okumaya yönelik tutum ölçeğinin geliştirilmesi: geçerlik ve güvenirlik çalışması,"Kastamonu Eğitim Dergisi, vol. 25(1), pp. 203-220, 2017.

[20] Güneyli, A., "Metin türlerine göre okuduğunu anlama becerisinin sınanması (Türkiye-Kuzey Kıbrıs Türk Cumhuriyeti üniversiteleri üzerinde bir araştırma)," Yayınlanmamış Yüksek Lisans Tezi. Ankara: Ankara Üniversitesi Sosyal Bilimler Enstitüsü, 2003.

Int. J. Eval. \& Res. Educ. Vol. 8, No. 1, March 2019: 181 - 188 